\title{
Improving Quality Level of Dining Table Through Painting Process by Using Taguchi Method
}

\author{
Eko Muh Widodo ${ }^{1, *}$ Oesman Raliby ${ }^{1}$ Tuesi Ari Purnomo ${ }^{1}$ Candra Widiarso ${ }^{1}$ \\ ${ }^{1}$ Industrial Engineering Departement, Faculty of Engineering, Muhammadiyah University of Magelang \\ *Corresponding author. Email: emwidodo@ummgl.ac.id
}

\begin{abstract}
In the process of painting a product, it commonly occur defect results including corrugated painting, perforated, less smooth, speckled and uneven surface of painting. This can occur due to the setting parameters in the process of painting is not appropriate. This research is done to reduce the high rate of defects in the process of painting products of table by setting parameters using the Taguchi method. Processing data using the Taguchi method are distinguished by two ways: (1) to see the impact of uncontrollable factors on the percentage of defective products and (2) to see the controllable factors to the variability of the number of defective products. Controllable factors in this study are: composition of paint, painting distance, pressure and temperature. The survey results revealed that a significant factor level against average and variability of percentage number of defective products are composition of the paint level $2(0.75: 1)$, the distance painting level $2(20-25 \mathrm{~cm})$, pressure level 1 (50 psi fluid tip round $1.88 \mathrm{~mm})$, temperature level $2\left(60^{\circ} \mathrm{C}\right)$, sanding sealer level $2(15-20 \mathrm{~cm})$ and a clear top coat level $1(20-2 \mathrm{Q} 5 \mathrm{~cm})$.
\end{abstract}

Keywords: Product Defects, Level factor, Taguchi

\section{INTRODUCTION}

The increasing demands of consumers and the development of science, technology, and information lead to changes in consumer tastes toward a product. Thus, consumer demand for the product will be more variety to fulfill the market segmentation that affects the tightness of the competitiveness of the company. One way to ensure that the product can compete and survive in the market is to control the quality of products. Furniture Company is a business that requires good quality control in term of aspects of components or finished products produced [1][2]. One important variable in the furniture company is the quality of painting process. One attempt to improve the quality of the product needs to be a good design parameter that defective products can be reduced. In this case the concept of quality control that is used is the Taguchi method [3][4].

Taguchi Concepts is a method to analyze a variety of variables and parameters in bulk and interactions among different variables to achieve a high quality which time and cost is relatively low [5][6]. The application of the method is expected to solve the problems of the company that is able to find the right parameters in reducing defects so that the products produced are in accordance with the specification set [7].

\subsection{Problems}

Based on the background of these problems, the research is done to improve the quality of painting furniture product so that it is to reduce the level of defects by (1) determining a significant factor level against the contribution of defect rate (2) determining the sensitive parameters to lower defective products and (3) comparing the level of defects between the policies of the company with the proposal based on setting parameter.

\section{METHOD}

The quality of the product is a combination of characteristics products and services both in terms of engineering, manufacturing, marketing and maintenance so as to meet customer needs [8]. To produce products that have a strong performance, Taguchi introduced the design method in three stages Isa $\mathrm{S}(1)$ designing system that is an attempt to bring the concepts, ideas and methods to improve the quality of products (2) designing parameters, that is selecting the best design of controllable factors and minimizing the environmental impact (3) designing tolerance, that is the stage of range 
to find a balance between making a loss (manufacturer) and buyer (consumer) products [6][9].

The Taguchi method is an effective method to reduce variation in products and processes through optimization process of designing the robust product using orthogonal array in the design of experimental procedures. Taguchi method also uses financial considerations through quadratic loss function to determine tolerance [10][5].

\section{RESULT AND DISCUSSION}

\subsection{Results}

In this study, there are two factors that can be identified as controlled factors and interference factors. Controllable factors are factors which its value can be set or factor which its value is to be regulated or controlled, while the interference factor is a factor which its value can't be regulated or controlled. Table 1 showing the control factors in the experiment. While uncontrolled factors are shown in Table 2. Table 3 is showing the results of calculation of average number of squares. Table 4 is showing first pooling effect factor ANOVA. Table 5 is showing Average Response Effect Each Factor, while table 6 is showing proposed composition. Table 7 is showing proposed composition experiment result, while Table 8 is showing composition company policy. And the last Table 9 is showing experiment result of company policy. In control experiments for each factor are two levels as follows:

Table 1. Controlled factors

\begin{tabular}{lcc}
\hline Factors Control & Composition 1 & Composition 2 \\
\hline Paint Composition & $0.5: 1$ & $0.75: 1$ \\
Distance Painting & $15-20 \mathrm{~cm}$ & $20-25 \mathrm{~cm}$ \\
Wind Pressure & 50 Psi Fluid tip & 60 Psi Fluid tip \\
& $\begin{array}{c}\text { Round } 1.8 \mathrm{~mm} \\
\pm 50 \text { minutes }\end{array}$ & Round $2 \mathrm{~mm}$ \\
wemperature & with a & \pm 50 minutes with a \\
& temperature of & temperature of $60^{\circ} \mathrm{C}$ \\
Sanding Sealer & $50^{\circ} \mathrm{C}$ & \\
Topcoat Clear & $20-25 \mathrm{~cm}$ & $15-20 \mathrm{~cm}$ \\
\hline
\end{tabular}

As for the uncontrolable factor is as follows:

Table 2. Factors not controlled

\begin{tabular}{lcc}
\multicolumn{1}{c}{$\begin{array}{c}\text { Factor Not } \\
\text { Controlled }\end{array}$} & Level & \\
\hline Working time & Morning & Noon \\
$\begin{array}{l}\text { Physical and } \\
\text { biological workers }\end{array}$ & Dedication & Extras \\
Environment & Comfort & Crowded \\
\hline
\end{tabular}

Table 3. The results of calculation of the average number of squares

\begin{tabular}{llll}
$\begin{array}{c}\text { Source of } \\
\text { variation }\end{array}$ & Df & $\begin{array}{c}\text { Sum of } \\
\text { Squares (SS) }\end{array}$ & $\begin{array}{c}\text { Mean of } \\
\text { Squares (MS) }\end{array}$ \\
\hline A & 1 & 20 & 20 \\
B & 1 & 16.78 & 16.78 \\
C & 1 & 16.78 & 16.78 \\
D & 1 & 37.03 & 37.03 \\
E & 1 & 56.18 & 56.18 \\
F & 1 & 18.37 & 18.37 \\
AB & 1 & 17.95 & 17.95 \\
BC & 1 & 15.32 & 15.32 \\
CD & 1 & 16.78 & 16.78 \\
DE & 1 & 20 & 20 \\
EF & 1 & 18.37 & 18.37 \\
E & 18 & 100.17 & 5.56 \\
SSt & 29 & 344 & 11.86 \\
\hline & & &
\end{tabular}

Incorporating factor starting from the number of the least squares of insignificant factor combined with the number of errors. The incorporation of an insignificant factor to these errors will result ANOVA table structure as follows:

Table 4. First Pooling Effect Factor ANOVA

\begin{tabular}{lllllll} 
Factor & Df & SS & M & SS & P & F. \\
\hline A & 1 & 20 & 20 & 14. & 5.8 & 3.59 \\
B & 1 & 16. & 16. & 11. & 4.8 & 3.01 \\
C & 1 & 16. & 16. & 11. & 4.8 & 3.01 \\
D & 1 & 37. & 37. & 31. & 10. & 6.66 \\
E & 1 & 56. & 56. & 50. & 16. & 10.1 \\
F & 1 & 18. & 18. & 12. & 5.3 & 3.30 \\
AB & 1 & 17. & 17. & 12. & 5.2 & 3.22 \\
BC & 1 & 15. & 15. & 9.7 & 4.5 & 2.75 \\
CD & 1 & 16. & 16. & 11. & 4.8 & 3.01 \\
DE & 1 & 20 & 20 & 14. & 5.8 & 3.59 \\
EF & 1 & 18. & 18. & 12. & 5.3 & 3.30 \\
E & 18 & 10 & 5.5 & & & \\
SS & 29 & 34 & 11. & & & \\
\hline
\end{tabular}

From the experimental results, controllable variables considered to be influence to the process of painting is the composition of paint used to compare the viscosity of 
paint (A), the distance of the painting process (B), the wind pressure when painting process $(\mathrm{C})$, the temperature used during the drying paint (D), sanding sealer when painting process (E) and a clear topcoat when painting process $(\mathrm{F})$. The test results are as follows:

Table 5. Average response effect each factor

\begin{tabular}{ccccl}
\hline Factor & Level 1 & Level 2 & Diference & Rank \\
\hline A & 3.22 & 2.72 & 0.5 & 5 \\
B & 3.05 & 2.88 & 0.17 & 1 \\
C & 2.88 & 3.05 & 0.17 & 1 \\
D & 3.22 & 2.88 & 0.34 & 3 \\
E & 3.22 & 3.05 & 0.17 & 1 \\
F & 2.83 & 3.11 & 0.28 & 2 \\
AB & 2.27 & 3.16 & 0.89 & 6 \\
BC & 2.83 & 3.00 & 0.17 & 1 \\
CD & 2.88 & 3.05 & 0.17 & 1 \\
DE & 3.22 & 2.72 & 0.45 & 4 \\
EF & 3.11 & 2.83 & 0.28 & 2 \\
\hline
\end{tabular}

After doing confirmation experiments to prove that the results are in accordance with previous experimental results. The experiments were conducted for 4 times, the first experiment uses set proposal as follows:

Table 6. Proposed composition

\begin{tabular}{lll}
\hline \multicolumn{1}{c}{ Level control } & Factors \\
\hline Paint composition & A2 \\
Painting distance & B2 \\
Wind pressure & C1 \\
temperature & D2 \\
Sanding sealer & E2 \\
Topcoat clear & F1 \\
\hline
\end{tabular}

The results of experiments using proposal composition as follows:

Based on the average of each factor and the calculated level can be explained most optimum level for defective product as follows:

Table 7. Proposed composition experiment results

\begin{tabular}{|c|c|c|c|c|}
\hline \multirow{2}{*}{\multicolumn{2}{|c|}{ Control factor Code }} & \multirow{2}{*}{ N Experiment } & \multicolumn{2}{|c|}{ Defective paint } \\
\hline & & & Unit & $\%$ Unit \\
\hline $\begin{array}{c}\text { Paint } \\
\text { Composition }\end{array}$ & A2 & 19 & 2 & 10.52 \\
\hline $\begin{array}{l}\text { Painting } \\
\text { distance }\end{array}$ & B2 & 19 & 2 & 10.52 \\
\hline Wind pressure & $\mathrm{C} 1$ & 19 & 1 & 5.26 \\
\hline temperature & D2 & 19 & 1 & 5.26 \\
\hline Sanding Sealer & E2 & 19 & 2 & 10.52 \\
\hline Topcoat clear & F1 & 19 & 2 & 10.52 \\
\hline Total & & & 10 & 56.60 \\
\hline Average & & & 1.67 & 8,76 \\
\hline $\mathrm{Sd}$ & & & 0.5163 & \\
\hline
\end{tabular}

The experiment using factor level of company policy is as follows:
Table 8. Composition of company policy

\begin{tabular}{ll} 
Control factor & Level \\
\hline Paint Composition & A1 \\
Painting distance & B1 \\
Wind pressure & C2 \\
temparature & D1 \\
Sanding sealer & E1 \\
Top coat clear & F2 \\
\hline
\end{tabular}

The experimental results using the composition of the company's policy as follows:

Table 9. Experiment results of company policy

\begin{tabular}{ccccc}
\hline Control factor & \multirow{2}{*}{ Code } & \multicolumn{2}{c}{$\mathrm{N}$} & \multicolumn{2}{c}{ Defective Product } \\
& & Experiment & Unit & \% Unit \\
\hline Paint Composition & A1 & 19 & 4 & 21.05 \\
Painting Distance & B1 & 19 & 4 & 21.05 \\
Wind Pressure & C2 & 19 & 3 & 15.78 \\
temperature & D1 & 19 & 5 & 26.31 \\
Sanding sealer & E1 & 19 & 3 & 15.78 \\
Top coat clear & F2 & 19 & 3 & 15.78 \\
Total & & & 22 & 115.75 \\
Average & & & 3.67 & 19.29 \\
Sd & & & 0.8164 & \\
\hline
\end{tabular}

\subsection{Discussion}

Based on the validation test is known that early experimental results that do not differ from the results of experimental confirmation. Loss function both composition proposal and company policies are shown in Figure 1 and 2. Loss costs as shown in the graph loss function for defective product, the proposed parameter with an average value of 1.67 and Ly 122,979.85 shown on the chart shown below:

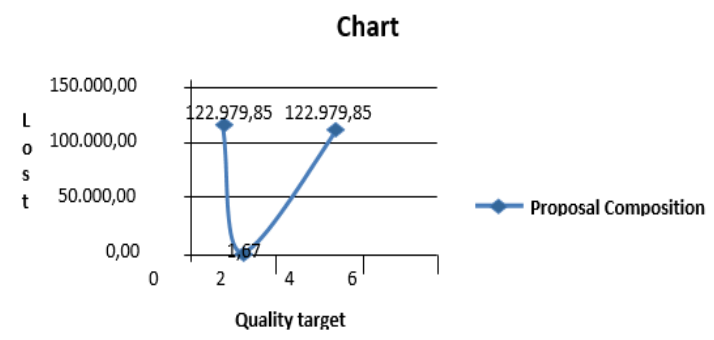

Figure 1 Loss function of composition proposal chart

While the loss function charts for defective products of company policy parameters with the average value of 3:00 and Ly 416,264, - is shown in the figure below:

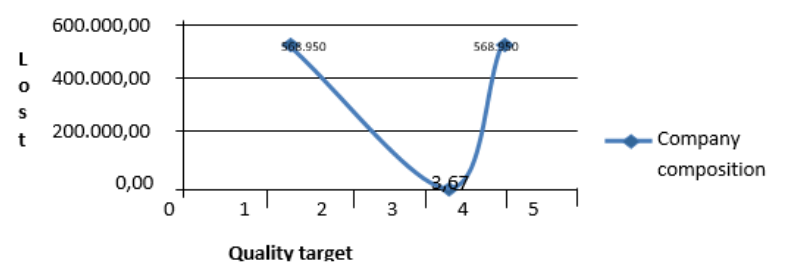

Figure 2 Lost function of company policies chart 


\section{CONCLUSION}

Based on the results of research and discussion, the following conclusions can be : Level factor that has significant contribution to the percentage of a defective product, are factor level of paint composition at B2 level, factor level of painting distance at B2 level, factor level of air pressure at $\mathrm{C} 1$ level, air temperature at D2 level, sanding Sealer at E2 level and clear coat top at F1 level. Sensitive parameters that affect the quality of the painting are the composition of paint, painting distance, air pressure, temperature, sanding sealer and top coat clear. Setting the parameters proposed by the research can reduce defects percentage from $19.29 \%$ to $8.76 \%$.

\section{REFERENCES}

[1] F. Gu, P. Hall, N. J. Miles, Q. Ding, and T. Wu, "Improvement of mechanical properties of recycled plastic blends via optimizing processing parameters using the Taguchi method and principal component analysis," Mater. Des., vol. 62, pp. 189-198, 2014, doi: 10.1016/j.matdes.2014.05.013.

[2] X. D. Diao, S. X. Zeng, and V. W. Y. Tam, "Development of an optimal trajectory model for spray painting on a free surface," Comput. Ind. Eng., vol. 57, no. 1, pp. 209-216, 2009, doi: 10.1016/j.cie.2008.11.010.

[3] S. K. Khare, G. S. Phull, and S. Agarwal, "Optimization the Machining Parameters of Surface Roughness during Micro-EDM by Taguchi Method," Mater. Today Proc., vol. 27, no. xxxx, pp. 475-479, 2019, doi: 10.1016/j.matpr.2019.11.279.

[4] R. Munprom and S. Limtasiri, "Optimization of stereolithographic 3D printing parameters using Taguchi method for improvement in mechanical properties," Mater. Today Proc., vol. 17, pp. 17681773, 2019, doi: 10.1016/j.matpr.2019.06.209.

[5] F. Gu, P. Hall, N. J. Miles, Q. Ding, and T. Wu, "Improvement of mechanical properties of recycled plastic blends via optimizing processing parameters using the Taguchi method and principal component analysis," Mater. Des., vol. 62, pp. 189-198, 2014, doi: 10.1016/j.matdes.2014.05.013.
[6] X. D. Diao, S. X. Zeng, and V. W. Y. Tam, "Development of an optimal trajectory model for spray painting on a free surface," Comput. Ind. Eng., vol. 57, no. 1, pp. 209-216, 2009, doi: 10.1016/j.cie.2008.11.010.

[7] S. K. Khare, G. S. Phull, and S. Agarwal, "Optimization the Machining Parameters of Surface Roughness during Micro-EDM by Taguchi Method," Mater. Today Proc., vol. 27, no. xxxx, pp. 475-479, 2019, doi: 10.1016/j.matpr.2019.11.279.

[8] R. Munprom and S. Limtasiri, "Optimization of stereolithographic 3D printing parameters using Taguchi method for improvement in mechanical properties," Mater. Today Proc., vol. 17, pp. 17681773, 2019, doi: 10.1016/j.matpr.2019.06.209.

[9] D. Wahjudi et al., "Optimasi Proses Injeksi Dengan Metode Taguchi," J. Tek. Mesin, vol. 3, no. 1, pp. 24-28-28, 2004, doi: 10.9744/jtm.3.1.pp.24-28.

[10]K. V. Sabarish and P. Paul, "An experimental analysis on structural beam with Taguchi orthogonal array," Mater. Today Proc., vol. 22, no. xxxx, pp. 874-878, 2020, doi: 10.1016/j.matpr.2019.11.049.

[11] I. W. Kuncoro, N. A. Pambudi, M. K. Biddinika, and C. W. Budiyanto, "Optimization of immersion cooling performance using the Taguchi Method," Case Stud. Therm. Eng., vol. 21, no. November 2019, p. 100729, 2020, doi: 10.1016/j.csite.2020.100729.

[12] U. Nunes, A. Batista, and J. Figueiredo, Spraypainting mo tion planning and quality analysis in powder coating systems, vol. 15, no. 1. IFAC, 2002.

[13] Suwarno, N. N. Debataraja, and S. W. Riski, "OPTIMASI KUALITAS HALLOW BLOCK DENGAN METODE TAGUCHI,” Bul. Ilm. Math. Stat. dan Ter., vol. 6, no. 01, pp. 61-68, 2017.

[14] A. Ustaoglu, B. Kursuncu, M. Alptekin, and M. S. Gok, "Performance optimization and parametric evaluation of the cascade vapor compression refrigeration cycle using Taguchi and ANOVA methods," Appl. Therm. Eng., p. 115816, 2020, doi: 10.1016/j.applthermaleng.2020.115816. 